\title{
Association between Intrauterine Growth Restriction and Pregnancy Hypertension
}

\author{
Nada Ardilla Dwiayu Febrina, ${ }^{1}$ Aris Primadi, ${ }^{2}$ Bony Wiem Lestari ${ }^{3}$ \\ ${ }^{1}$ Faculty of Medicine Universitas Padjadjaran, ${ }^{2}$ Department of Child Health Faculty of Medicine \\ Universitas Padjadjaran/Dr. Hasan Sadikin General Hospital, Bandung, ${ }^{3}$ Department of \\ Epidemiology and Biostatistics, Faculty of Medicine Universitas Padjadjaran
}

\begin{abstract}
Background: Intrauterine Growth Restriction (IUGR) certainly poses health problems that leads to increase mortality and can cause mental and physiological disturbances to the infants. Reduced organ perfusion is one of the etiologies of IUGR which is caused by placenta obstruction. This happens because of pregnancy hypertension as a risk factor. Furthermore, educational level, employment status, parity, and anemia are also its risk factors. The objective of this study was to analyze the prevalence of IUGR and association between IUGR and pregnancy hypertension.

Methods: A case control design was performed using medical records from Neonatology Department of Child Health at Dr. Hasan Sadikin General Hospital Bandung in 2012. Subjects were taken from 149 medical records of the mother who had IUGR and 149 normal birth weight infant information about the characteristics of the mothers and the infants. The data were collected and analyzed by calculating the Odds ratio (OR).

Results: The prevalence of IUGR at Dr. Hasan Sadikin General Hospital in 2012 was 149 cases (4.69\%). There was association between pregnancy hypertension and IUGR with OR=1.72, 95\% CI (1.044-2.836).

Conclusions: Pregnancy hypertension is one of the risks that generates IUGR. [AMJ,2016;3(2):212-5]

Keywords: Intrauterine growth restriction, pregnancy hypertension, risk factor
\end{abstract}

\section{Introduction}

Intrauterine Growth Restriction (IUGR) is still one of the health problems and is closely related to mortality. ${ }^{1-3}$ The mortality risk ratio of IUGR ranges from six to ten times higher compared to a normal infant. ${ }^{1}$ The IUGR can also cause retarded physiology as well as lower intellectual scale 1 level compared to infants with normal weight. ${ }^{4}$ In Indonesia, during 2004-2005, the prevalence of IUGR was $4.4 \%{ }^{5}$

The IUGR babies have been associated with cardiovascular disease in pregnancy. One of the factors that have been postulated to influence the IUGR risk among the newborn is hypertension..$^{6-8}$ Furthermore, educational level, employment status, parity, and anemia are among others of the the risk factors. In Pakistan, Muhammad et al. ${ }^{7}$ discovered that in 2010, pregnancy hypertension had a high risk causing IUGR with OR (odds ratio)=3.8. This study was conducted to identify the association between IUGR and pregnancy hypertension.

\section{Methods}

This study was analytical study with case control design and used secondary data (medical records) from Neonatology Department of Child Health at Dr. Hasan Sadikin General Hospital Bandung in 2012. The criteria of IUGR interpreted by the Lubchenco Curve were inputted when the infant weight were less than $10 \%$ of the least weight that should be achieved at a particular gestational age. From 185 medical records consisting of IUGR babies data, only 149 medical records that fulfilled the inclusion criteria, namely data of patient's characteristic such as educational level, employment status, parity, anemia, and hypertension. The control group was medical records consisted of normal birth weight babies data that also met the similar inclusion criteria.

The ratio of case and control group of this

Correspondence: Nada Ardilla Dwiayu Febrina, Faculty of Medicine, Universitas Padjadjaran, Jalan Raya BandungSumedang Km.21, Jatinangor, Sumedang, Indonesia, Phone: +6281214700740 Email: nadaardilla@gmail.com 
Table 1 Prevalence of IUGR at Dr. Hasan Sadikin General Hospital Bandung

\begin{tabular}{lcc}
\hline \multicolumn{1}{c}{ Intrauterine Growth } & N & \% \\
\hline Intrauterine Growth Restriction & 149 & 4.69 \\
Normal and Large for Gestational Age & 3025 & 95.3 \\
Total & 3174 & 100 \\
\hline
\end{tabular}

research was 1:1. The selected control group was matched by simple random sampling based on patients age from case group (16-44 years old).

The exclusion criteria were those data of incomplete variable, double pregnancy, and infants whose weight are beyond 500 grams. Clinical criteria of pregnancy hypertension implying BP $\geq 140 / 90$ and all classifications of pregnancy hypertension were included.

The collected data were analyzed using computer and presented by frequency distribution. Statistical analysis was conducted by calculated odd ratio, confidence interval, and Chi square test.

Table 2 Characteristics of Mothers with Intrauterine Growth Restriction at Dr. Hasan Sadikin General Hospital Bandung

\begin{tabular}{|c|c|c|c|c|c|}
\hline \multirow{3}{*}{ Variable } & \multicolumn{4}{|c|}{ Intrauterine Growth Restriction } & \multirow{3}{*}{ OR(95\%CI) } \\
\hline & \multicolumn{2}{|c|}{ Yes } & \multicolumn{2}{|c|}{ No } & \\
\hline & $\mathbf{N}$ & $\%$ & $\mathbf{N}$ & $\%$ & \\
\hline \multicolumn{6}{|l|}{ Age (years old) } \\
\hline$<18$ & 2 & 50 & 2 & 50 & 1 \\
\hline $18-34$ & 111 & 50 & 111 & 50 & \\
\hline$\geq 35$ & 36 & 50 & 36 & 50 & \\
\hline \multicolumn{6}{|l|}{ Educational Level } \\
\hline Elementary school & 38 & 57.6 & 28 & 42.4 & $1.479(0.852-2.569)$ \\
\hline Junior high school & 49 & 49.5 & 50 & 50.5 & 0.97 \\
\hline Senior high school & 43 & 47.8 & 47 & 52.2 & 0.88 \\
\hline Diploma & 11 & 52.4 & 10 & 47.6 & 1 \\
\hline Bachelor & 8 & 36.4 & 14 & 63.6 & 0.547 \\
\hline \multicolumn{6}{|l|}{ Employment status } \\
\hline Employment & 31 & 54.4 & 26 & 45.6 & $1.243(0.696-2.218)$ \\
\hline Unemployment & 118 & 49 & 123 & 51 & \\
\hline \multicolumn{6}{|l|}{ Parity } \\
\hline Nullipara & 65 & 48.9 & 68 & 51.1 & 0.922 \\
\hline Primipara & 47 & 58 & 34 & 41.9 & $1.559(1.931-2.610)$ \\
\hline Multipara & 34 & 42.5 & 46 & 57.5 & 0.662 \\
\hline Grand Multipara & 3 & 75 & 1 & 25 & $3.041(0.313-29.574)$ \\
\hline \multicolumn{6}{|l|}{ Anemia } \\
\hline Yes & 34 & 22.8 & 34 & 22.8 & 1 \\
\hline No & 115 & 77.2 & 115 & 77.2 & \\
\hline Gestational Age (week) & \multicolumn{2}{|c|}{$36.83(2.26)$} & \multicolumn{2}{|c|}{$38.34(1.8)$} & \\
\hline Infant weight (gr) & \multicolumn{2}{|c|}{$2121.97(411.2)$} & \multicolumn{2}{|c|}{$2994(542.52)$} & \\
\hline
\end{tabular}


Table 3 IUGR Cases based on Pregnancy Hypertension at Dr. Hasan Sadikin General Hospital Bandung

\begin{tabular}{|c|c|c|c|c|c|c|}
\hline \multirow{3}{*}{ Variable } & \multicolumn{4}{|c|}{ Intrauterine Growth Restriction } & \multirow{3}{*}{$\left.\mathbf{p}^{*}\right)$} & \multirow{3}{*}{ OR(95\%CI) } \\
\hline & \multicolumn{2}{|c|}{$\begin{array}{c}\text { Yes } \\
(n=149)\end{array}$} & \multicolumn{2}{|c|}{$\begin{array}{c}\text { No } \\
(n=149)\end{array}$} & & \\
\hline & $\mathrm{N}$ & $\%$ & $\mathrm{~N}$ & $\%$ & & \\
\hline \multicolumn{7}{|c|}{ Pregnancy Hypertension } \\
\hline Yes & 54 & 59.3 & 37 & 40.7 & 0.032 & $1.721(1.044-2.836)$ \\
\hline No & 95 & 45.9 & 112 & 54.1 & & \\
\hline
\end{tabular}

\section{Results}

Prevalence of IUGR at Dr. Hasan Sadikin General Hospital Bandung in 2012 was 185 cases from 3174 labor. From the total incidence of IUGR, there were 149 cases put into criteria inclusion and the others (36 cases) put into criteria exclusion because the incomplete variables were requested. So, prevalence of IUGR at Dr. Hasan Sadikin General Hospital Bandung in 2012 was $4.69 \%$.

Mothers with low education tend to have IUGR 1.479 times compared to mother with higher education. Based on employment status, IUGR cases were discovered 1.243 times in employed mothers compared to non employed mothers. Moreover, IUGR cases were discovered in grand multipara mothers 3.041 times compared to non grand multipara cases. However, anemia was not the higher risk to generate IUGR cases because the odds ratio was 1 (Table 2 ).

The IUGR cases occured more often in pregnancy hypertension cases (59.3\%) (Table 3). Statistical analysis using Chi Square Test with 95\% accuracy revealed that odds ratio of IUGR cases in pregnancy hypertension was 1.72 .

\section{Discussions}

The prevalence of IUGR at Dr. Hasan Sadikin General Hospital Bandung in 2012 was $4.6 \%$. This result was similar to a study in Indonesia ${ }^{5}$ during 2004-2005 that revealed the prevalence of IUGR was $4.4 \%{ }^{5}$

The result in this study showed that IUGR cases were discovered in mothers with low education. This study had result with the study conducted in Pakistan. ${ }^{7}$ The study result showed that the majority of IUGR cases were from illiterate mothers (88.8\%). Based on study in 2010 by Muhammad et al. ${ }^{7}$, mother who was grand multipara was $12 \%$. In this study, mother who was grand multipara was $75 \%$. Study by De Farias Aragao et al. ${ }^{9}$ also discovered that maternal education and parity were associated with IUGR. The percentage in mothers with anemia associated with IUGR in this study was $22.8 \%$ and this result had the similar result to the study in Pakistan that in IUGR cases, $15 \%$ mothers have anemia. ${ }^{7}$

The IUGR cases occured more often in pregnancy hypertension cases. Pregnancy hypertension tend to have IUGR cases 1.72 times more than non pregnancy hypertension. A similar result was discovered in a study by Kalanithi et al. ${ }^{2}$ in 2007, which explained that there was a significant relationship between hypertensionin pregnancy and IUGR $(\mathrm{p}<0.001)$, which means a high risk of hypertension in pregnancy will cause IUGR. Another study in Norway ${ }^{11}$ in 2006, discovered that severe preeclampsia, one of the classifications of pregnancy hypertension, had risk of IUGR with $\mathrm{OR}=1.8$. Study from Maryland ${ }^{12}$ also had a similar result that pregnancy hypertension was significantly associated with high risk of IUGR with $\mathrm{OR}=1.5$ for preeclampsia-eclampsia as pregnancy hypertension. Moreover, a study conducted by Muhammad et al. ${ }^{7}$ in Pakistan, discovered that hypertension in pregnancy has a higher risk of causing IUGR with $\mathrm{OR}=3.8$.

The study had limitation. Using medical records as source of data has disadvantages. Not all the information requested in this study were available. From 185 medical records selected, 36 of them were excluded. It can be concluded that pregnancy hypertension is the risk to generate IUGR cases.

\section{References}

1. Prawirohardjo S. Ilmu kebidanan. 4thed. Jakarta: PT. Bina Pustaka; 2009.

2. Kalanithi LEG, Illuzzi JL, Nossov VB, 
Frisbaek Y, Abdel-Razeq S, Copel JA, et al. Intrauterine growth restriction and placental location. J Ultrasound Med. 2007;26(11):1481-9.

3. Bernstein IM, Horbar JD, Badger GJ, Ohlsson A, Golan A. Morbidity and mortality among very-low-birth-weight neonates with intrauterine growth restriction. Am J Obstet Gynecol. 2000;182(1 Pt 1):198206.

4. Sistiarani C. Faktor maternal dan kualitas pelayanan antenatal yang berisiko terhadap kejadian berat badan lahir rendah [thesis]. Semarang: Universitas Diponegoro; 2008.

5. Christian HS. Berat bayi lahir rendah sesuai untuk masa kehamilan [thesis]. Jakarta: Universitas Kristen Krida Wacana; 2006.

6. Sibai BM. Intergenerational factors: a missing link for preeclampsia, fetal growth restriction, and cardiovascular disease? Hypertension. 2008;51(4):993-4.

7. Muhammad T, Khattak AA, Shafiqur-Rehman, Khan MA, Khan A, Khan MA. Maternal factors associated with intrauterine growth restriction. J Ayub Med Coll Abbottabad. 2010;22(4):64-9.

8. Baulon E, Fraser WD, Piedboeuf B, Buekens P, Xiong X. Pregnancy-induced hypertension and infant growth at 28 and 42 days postpartum. BMC Pregnancy Childbirth. 2005;5:10.

9. De Farias Aragao VM, Barbieri MA, Moura Da Silva AA, Bettiol H, Ribeiro VS. Risk factor for intrauterine growth restriction: a comparison between two brazilian cities. Pediatr Res. 2005;57(5 Pt 1):674-9.

10. Aghamolaei T, Eftekhar H, Zare S. Risk factors associated with intrauterine growth retardation in Bandar Abbas. J Med Sci. 2007;7(4):665-9.

11. Rasmussen S, Irgens LM. The effects of smoking and hypertensive disorders on fetal growth. BMC Pregnancy Childbirth. 2006;6:16.

12. Wen X, Triche EW, Hogan JW, Shenassa ED, Buka SL. Prenatal factors for childhood blood pressure mediated by intrauterine and/or childhood growth? Pediatrics. 2011;127(3):e713-21. 